\title{
Degradation of methomyl by the novel bacterial strain Stenotrophomonas maltophilia M1
}

\author{
Mervat S. Mohamed \\ Faculty of Science \\ Cairo University, Egypt \\ E-mail: mervat@cu.edu.eg
}

Financial support: Cairo University.

Keywords: carbamate, methomyl, plasmid, SPE-LC-ESI-MS, Stenotrophomonas.

\author{
Abbreviations: LB: Luria Bertani \\ MSM: minimal salt medium \\ PCR: polymerase chain reaction \\ SPE-LC-ESI-MS: solid phased extraction coupled to capillary liquid chromatography-electrospray ionization-mass spectrometry
}

The use of microorganisms in the degradation and detoxification of many toxic xenobiotics, especially pesticides, is an efficient tool for the decontamination of polluted sites in the environment. A novel bacterial strain (M1) was isolated from several water samples contaminated with methomyl which is capable of degrading methomyl pesticide (1000 ppm) in the presence of $0.05 \%$ glucose. These water samples were collected from different irrigation sites in Egypt where methomyl is heavily applied. The partial sequence of 16SrRNA gene of the isolate showed the highest similarity to Stenotrophomonas maltophilia. Restriction fragment patterns of isolated plasmid DNA showed that this strain harbours two different plasmids PMa (8Kb) and PMb (5Kb). PMb succeeded to be transferred to Escherichia coli DH5a strain. This transformed strain (M2) acquired the ability to grow in the presence of methomyl (1000 ppm) and $0.05 \%$ glucose. So it was deduced that the gene responsible for the degradation process was encoded by this plasmid. The ability of the two strains M1 and M2 to degrade methomyl was detected by using solid phased extraction coupled to capillary liquid chromatography-electrospray ionization-mass spectrometry (SPE-LC-ESI-MS).

The excessive use of pesticides leads to an accumulation of a huge amount of residues in the environment, thereby posing a substantial health hazard for the current and future generations due to uptake and accumulation of these toxic compounds in the food chain and drinking water. Bioremediation constitutes an attractive alternative to physico-chemical methods of remediation, as it is less expensive and can selectively achieve complete destruction of organic pollutants (Alexander, 1999). Methomyl belongs to a class of compounds known as oxime carbamates, and it is widely used for the control of insects and nematode pests by inhibiting the enzyme acetylcholinesterase which hydrolyzes the neurotransmitter acetylcholine. The IUPAC name of methomyl is S-methyl N- (methylcarbamoyloxy) thioacetimidate (Tomlin, 2003). The WHO (World Health Organization), EPA (Environment Protection Agency) and ECC (European Chemical Classification) classify methomyl as a very toxic and hazardous pesticide. Methomyl is highly soluble in water $\left(57.9 \mathrm{~g} / \mathrm{liter}\right.$, at $25^{\circ} \mathrm{C}$ (Tomlin, 2003), and since the sorption affinity of soils for this pollutant is rather low, it can easily cause contamination of both ground and surface water resources (Strathmann and Stone, 2001).

At the same time; microorganisms are thought to play an important role in the removal and detoxification of these toxicants from the environment. Many bacteria that are able to degrade carbamate pesticides have been isolated from soil around the world (Desaint et al. 2000). Many pesticide degradation genes present in soil bacteria have been shown to reside on plasmids, a common location for other degradation genes (Chung and Ka, 1998; Laemmli et al. 2000). Plasmids that bear genes encoding for enzymes capable of degradation have been of great attraction where these plasmids, known as catabolic plasmids, can give the organism containing them the ability to degrade certain compounds. Many catabolic plasmids have been found in species of Pseudomonas, Alcaligenes, Actinobacter, Flavobacterium, Klebsiella, Moraxella and Arthrobacter (Sayler et al. 1990). Conventional approaches (e.g. landfilling, recycling, pyrolysis and incineration) to the remediation of contaminated sites are inefficient and costly and can also lead to the formation of toxic intermediates (Dua et al. 2002). Thus, biological decontamination methods are preferable to conventional approaches because, in general, microorganisms degrade numerous environmental pollutants without producing toxic intermediates (Pieper and Reineke, 2000; Furukawa, 2003).

In this study, several bacterial strains were isolated. Only one bacterial strain was isolated and identified which had the ability to degrade high concentrations of methomyl up to $(1000 \mathrm{ppm})$ in the presence of $0.05 \%$ glucose. The 


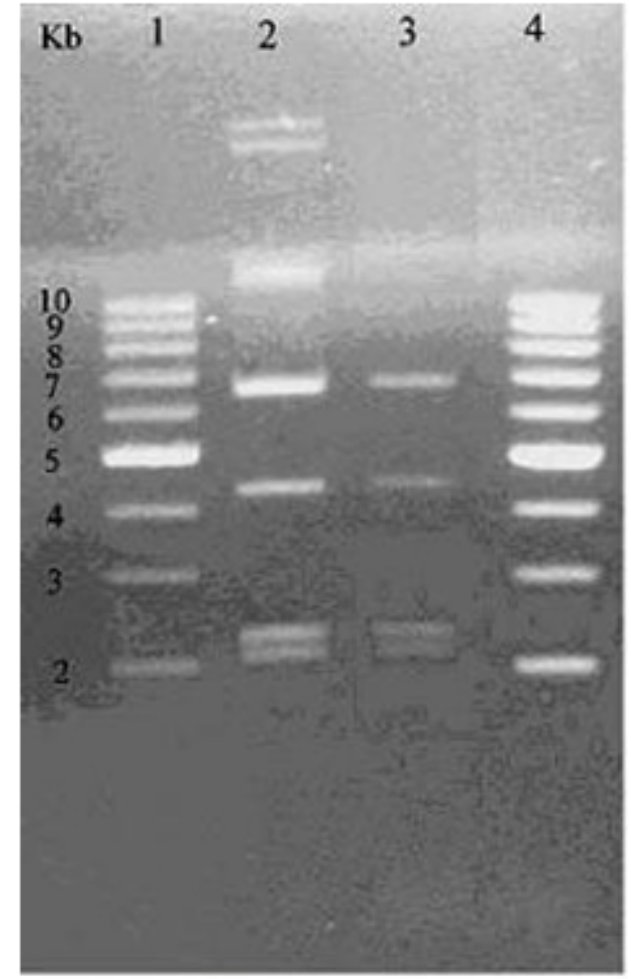

Figure 1. Isolated plasmid from Stenotrophomonas maltophilia M1 strain and transformed E-Coli. Lane 1 and lane 4 represent supercoiled DNA ladder. Lane 2 represents the plasmids harbour in strain M1. Lane 3 represents the transformed plasmids to E-Coli.

plasmid bearing gene (s) was transferred to Escherichia coli DH5 $\alpha$ strain and the transformed strain acquired the ability for methomyl degradation. The degradation ability of both strains was confirmed by solid phased extraction coupled to capillary liquid chromatography-electrospray ionizationmass spectrometry (SPE-LC-ESI-MS) analysis.

\section{MATERIALS AND METHODS}

\section{Isolation and identification of methomyl-degrading bacterial strain}

Several water samples were collected from wasted water contaminated with pesticides from different agricultural fields in Egypt, as a source of methomyl degrading bacteria. $1 \mathrm{ml}$ from each water sample was added to $20 \mathrm{ml}$ of autoclaved M9 minimal salt medium (MSM) containing methomyl (100 ppm) as a sole carbon and energy source. Cultures were incubated in an orbital shaker at $30^{\circ} \mathrm{C}$ and $160 \mathrm{rpm}$ for 7 days, $1 \mathrm{ml}$ of each enrichment cultures was then transferred to $20 \mathrm{ml}$ of fresh autoclaved minimal medium and incubated for additional 7 days under the same conditions. After enrichment cultivation, $0.1 \mathrm{ml}$ of the culture was spread on minimal salt agar plates (MSA, MM containing $1.5 \%$ Bacto Noble Agar) that contained methomyl (100 ppm) as a sole carbon source. The plates were then incubated at $30^{\circ} \mathrm{C}$ for a week. A colony from each isolate was then used to inoculate $20 \mathrm{ml}$ of MSM containing methomyl (100 ppm) and incubated for a week in an orbital shaker under the same condtion in order to confirm the biodegradability. The strain that showed notable growth under this condition was selected as a possible methomyl degrader and designated as M1 it also showed the abiltiy to grow in the presence of relatively high concentration of methomyl (1000 ppm) in the presence of $0.05 \%$ glucose. Fresh cultures from a $-20^{\circ} \mathrm{C}$ stock were regularly obtained to ensure maintenance of the degradative phenotype.

\section{Characterisation and identification of isolated bacterial strain}

The selected isolated bacterial strain was characterised and identified on the basis of physiological microbiological and biochemical characterisation (Duguid et al. 1996) also it was subjected to further molecular characterization by polymerase chain reaction (PCR) amplification and partial sequence analysis of the 16S rRNA gene. The amplification was carried out by using PCR master mix kit (Promega) according to the manufacturer's instructions. Universal primers pairs 9F and 1512R were used to amplify 1500 bp. These primers are used to amplify the 16S rRNA gene of most eubacteria (Weisburg et al. 1991). PCR products were purified by Wizard ${ }^{\circledR}$ SV Gel and PCR cleaning up system kit (Promega) following the protocol provided by

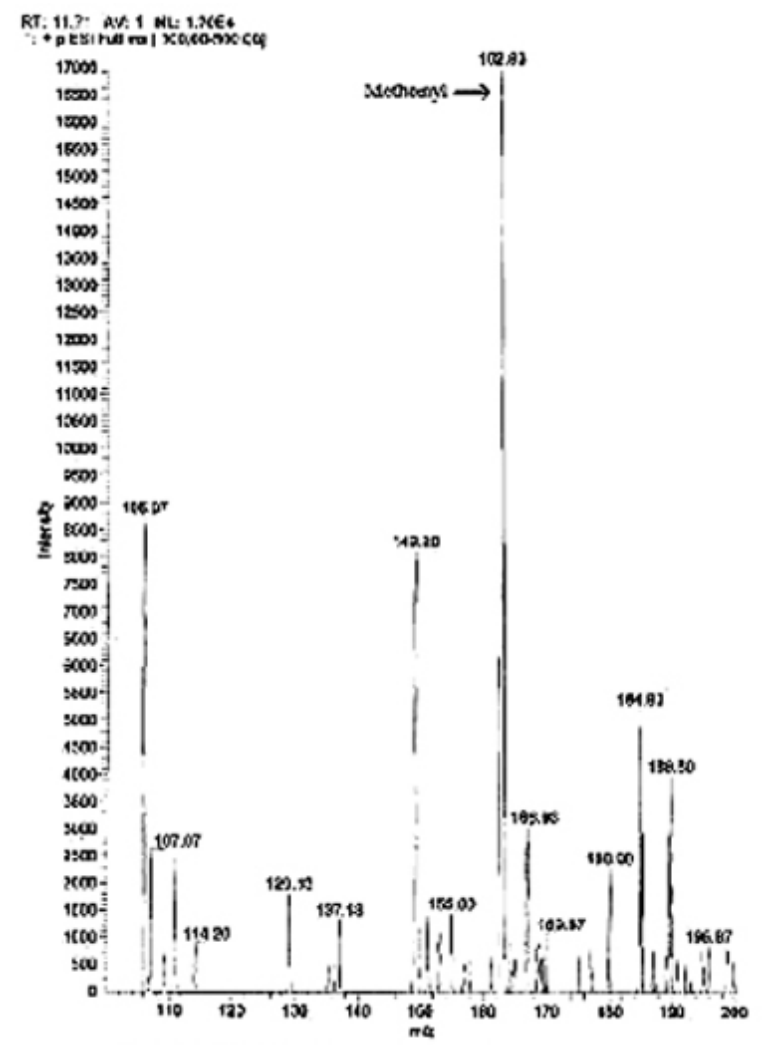

Figure 2. LC-ESI-MS of the standard sample. 
the supplier and then resolved by electrophoresis on $1 \%$ agarose gel. The purified products were sequenced. The sequence of the 16S rRNA of the strain was compared with another 16S rRNA sequences that were published on the NCBI database [http://www.ncbi.nlm.nih.gov]. That was done using the BLAST program to determine the nearest phylogenetic neighbors and to compare it with previously published sequences.

\section{Plasmid DNA isolation}

Plasmid DNA was isolated from M1 strain by using Wizard ${ }^{\circledR}$ Plus SV Minipreps DNA purification system kit (Promega) following the manufacturer's recommended protocol. Isolated plasmid DNA (usually $10 \mu \mathrm{l}$ ) was analyzed by gel electrophoresis (0.7\% [wt/vol] agarose). Restriction enzymes Bam H1, EcoRI, Hind III, Pst1 and Sau3A were used to detect the number of plasmids in the this strain.

\section{Transformation experiment}

Isolated plasmids carrying the degrading gene (s) from M1 strain, was strongly suggested to be responsible for methomyl degradation. Therefore, the plasmid DNA was transferred to E. coli DH5 $\alpha$ strain by transformation. Two microliters of the plasmids were transferred into $E$. coli DH5 $\alpha$ competent cells. After transformation the cells were plated on a Luria Bertani (LB) agar plates containing methomyl (100 ppm) and allowed to grow for 16 hrs at $37^{\circ} \mathrm{C}$. Methomyl pesticide was used to select $E$. coli with plasmid (s) which had the ability to degrade it. During this double selection, the pesticide killed any E. coli that lacked the plasmid (s) carrying the degradative gene (s). Single colonies were inoculated in liquid cultures, allowed to grow overnight, and stored as glycerol stocks. $5 \mu \mathrm{l}$ of the stock was inoculated into $10 \mathrm{ml}$ LB containing (500 ppm) methomyl for subsequent plasmid DNA preparation. Electrophoresis was carried out at $90 \mathrm{v}$ for $1 \mathrm{hrs}(0.7 \%$ [wt/vol] agarose).

\section{Analytical technique}

Degradation of methomyl by M1 and M2 strains in liquid media was confirmed by solid- phase extraction SPE-LCESI-MS assays. All samples were prepared in triplicate; the first one (standard sample) was a non-inoculated sample containing methomyl (100 ppm) in $20 \mathrm{ml}$ of M9 minimal salt medium and $0.05 \%$ glucose, only kept as a control. In the second sample (the original one), a single colony from original strain (M1) was used to inoculate $20 \mathrm{ml}$ of M9 minimal salt medium containing methomyl (100 ppm) and $0.05 \%$ glucose. The third one (transformed sample) M2 was used as inoculum in the same medium. All cultures were incubated in an orbital shaker for $48 \mathrm{hrs}$ at $150 \mathrm{rpm}$ at $30^{\circ} \mathrm{C}$. Methomyl was extracted from the liquid media by solid phase extraction method in which each cartridge (Oasis
HLB, water; $6 \mathrm{ml}, 200 \mathrm{mg}$ ) was conditioned with $3 \mathrm{ml}$ of methanol-acetonitrile $(50: 50, \mathrm{v} / \mathrm{v})$. Each sample $(20 \mathrm{ml})$ was passed through the cartridge at a flow rate of $1 \mathrm{ml} / \mathrm{min}$. After extraction of the water sample, the cartridges were dried by centrifugation at $3000 \mathrm{rpm}$ for $3 \mathrm{~min}$. The column was washed twice with $3 \mathrm{ml}$ of deionized water, followed by air drying for $2 \mathrm{~min}$. Subsequently, the elution of the pesticide took place with three volumes of $1 \mathrm{ml}$ of methanol-acetonitrile (50:50, V/V). The residues were left to dry then redissolved in $200 \mu \mathrm{l}$ of deionized water. After agitation by vortex they were analyzed by LC-ESI-MS. The analyses were carried out by LCQ Advantage Max from Thermo Electron Corporation. C18 Hyperpurity column (25 cm x $4.6 \mathrm{~mm}, 5-\mu \mathrm{m}$ particle size) was used. The mobile phase consisted of acetonitrile: water $(25: 75 \%, \mathrm{v} / \mathrm{v})$ with $0.1 \%$ formic acid (w/v) as proton source was eluted at a flow rate of $0.5 \mathrm{ml} / \mathrm{min}$. Atmospheric pressure ESI was carried out in the positive mode. In the full-SCAN mode the parameters were as follows: mass range $\mathrm{m} / \mathrm{z}$ from 50 200 using a 0.1 unit step size dry gas flow $\left(\mathrm{N}_{2}\right) 10 \mathrm{l} / \mathrm{min}$, nebulizer pressure $50 \mathrm{psi}$, drying gas temperature $350^{\circ} \mathrm{C}$ and capillary voltage at $3500 \mathrm{~V}$. All samples were analyzed within 2 hrs after elution.

\section{Data analysis}

Standard deviation on means and $p$ value were calculated using Sigma Plot software. A $p$ value of less than 0.05 was considered statistically significant.

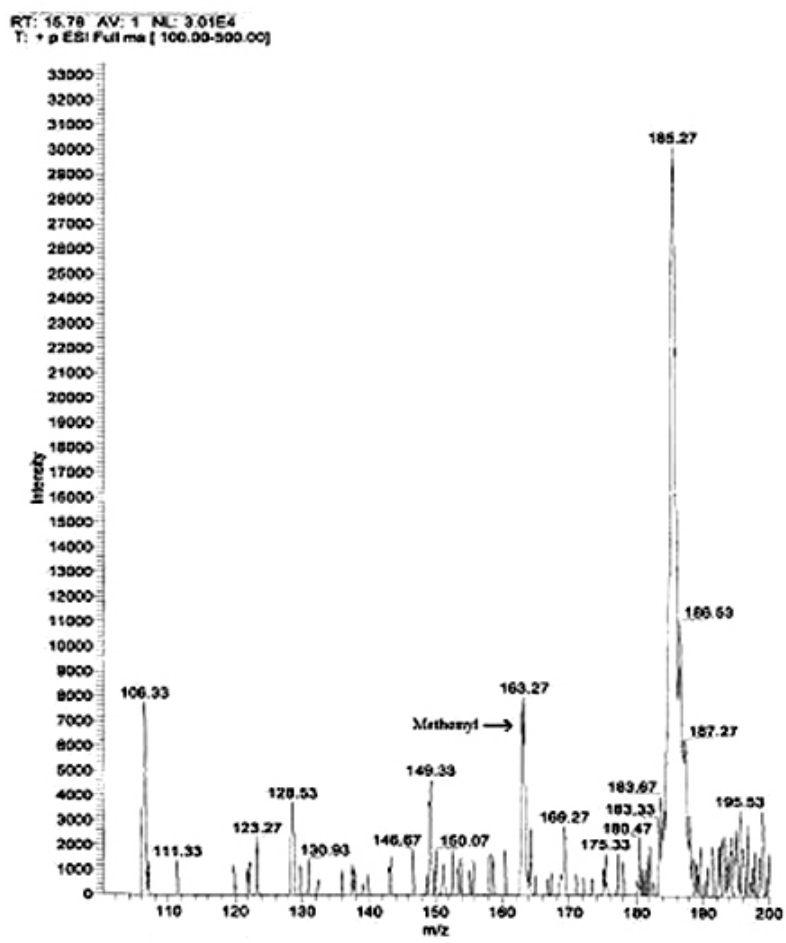

Figure 3. LC-ESI-MS of the original strain. 


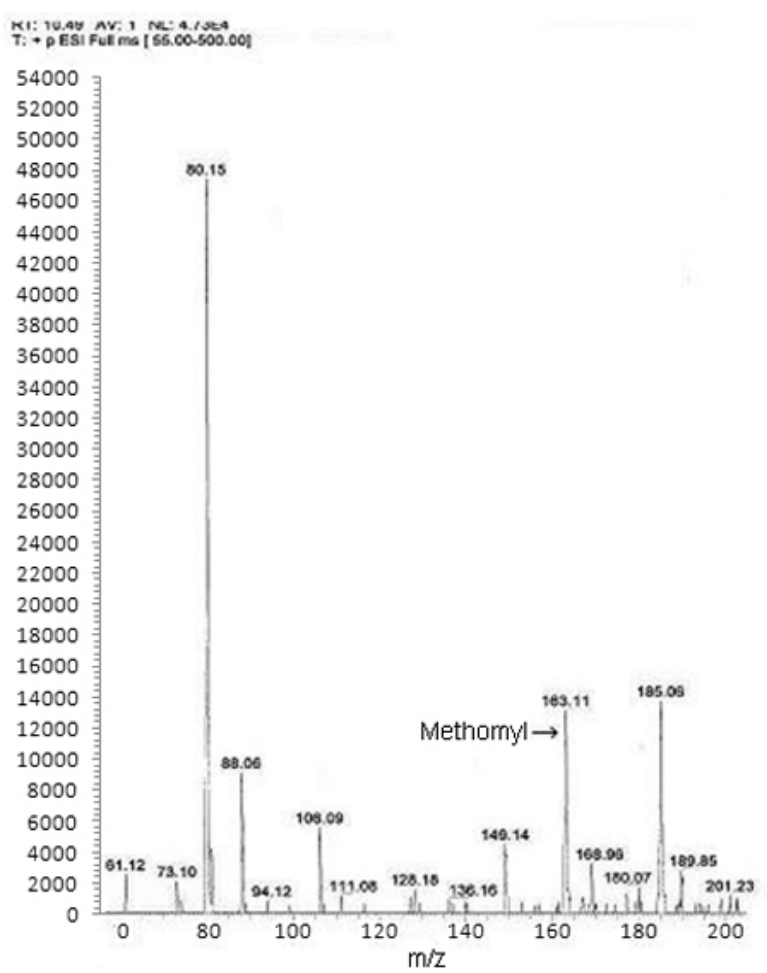

Figure 4. LC-ESI-MS of the transformed strain.

\section{RESULTS AND DISCUSSION}

\section{Characterization and identification of methomyl - degrading isolate}

The enrichment procedure generated a pure culture, designated as M1, which is able to grow in minimal media containing methomyl (100 ppm) as a sole source of carbon. Furthermore, this bacterium tolerates a high level of methomyl up to $1000 \mathrm{ppm}$ in the presence of $0.05 \%$ glucose. Taxonomic characterization of M1 strain revealed that it is gram - negative, aerobic, motile, oxidase negative and catalase positive. Partial sequence analysis of the amplified 16S rRNA gene confirmed the classification of the isolate as a member of the genus Stenotrophomonas where it showed the highest degree of similarity (99\%) to that of Stenotrophomonas maltophilia. Based upon this finding, the isolate was designated as Stenotrophomonas maltophilia M1 strain. It has been reported that $S$. maltophilia is able to degrade many xenobiotic compounds (Lee et al. 2002) and to detoxify high molecular weight polycyclic aromatic hydrocarbons (Juhasz et al. 2000). Therefore, it possesses a potential for soil decontamination (bioremediation).

\section{Plasmid DNA profiling of M1 strain}

The plasmid extraction method, previously described, was used to extract the plasmid encoding the methomyl degrading gene (s) from strain M1. The size of the plasmids were estimated on the basis of electrophoretic mobility of the isolated fragments as compared to the sizes of Promega supercoiled marker as shown in Figure 1. Analysis of the restriction fingerprint patterns of the plasmids of strain M1 was done after treatment with each of EcoRI, BamHI, HindIII, Pst1 and Sau3A restriction enzymes. The first three restriction enzymes yielded two bands at $8 \mathrm{~kb}$ and 5 $\mathrm{kb}$ which indicated that the strain M1 harboured two different plasmids (PMa and PMb) and each plasmid had only one restriction site for these enzymes Sau3A was found to have more than one restriction site in each plasmid yielding different bands at different sizes while PstI was had no restriction sites on any plasmid (data not shown). The involvement of naturally occurring plasmids in the degradation of carbaryl has been extensively documented (Hashimoto et al. 2002). Catabolic plasmids are thought to play an important role in the evolution of pesticide degrading ability in microorganisms (Sayler et al. 1990).

\section{Transformation of another bacterial strain with the gene bearing-plasmid}

The two plasmids PMa and PMb were used to transform $E$. coli DH5 $\alpha$ strain. Only PMb plasmid $(5 \mathrm{~kb})$ was successfully transferred to this strain to allow it to grow on methomyl while PMa plasmid was not detected and may lack the gene responsible for the degradation process. Positive transformants were selected on a minimal salt agar plates that contains $100 \mathrm{ppm}$ methomyl. This strain (transformed strain) had the ability to hydrolyze methomyl (100 ppm) in M9 media and maintain its activity after repeated subculture. The plasmid profile of the transformed cells was analyzed by agarose gel electrophoresis as shown in Figure 1. The location of the degradative genes on plasmids can aid or promote transfer to other strains and lead to an increase in the metabolic diversity of the soil microbial population. Marecik et al. (2008) reported that the positive effect of microorganisms in the process of xenobiotic degradation can be explained in terms of a variety of different species and a broad spectrum of produced enzymes. Microorganisms can therefore use different sources of carbon and nitrogen to adapt to different environments.

Also, new gene combinations could allow the degradation of related compounds, degradation via different pathways, or recombination between related genes to generate even greater metabolic diversity (Karns, 1990). When this plasmid is genetically transferred to a new host it confers the capacity to metabolize the compound of interest.

\section{Monitoring of the degradation of methomyl by SPE-LC-ESI-MS}

The capability of both strains M1 and M2 to degrade the methomyl was detected by a method for the ultra-trace analysis, using solid-phase extraction followed by electrospray ionisation mass spectrometry (SPE-LC-ESI- 


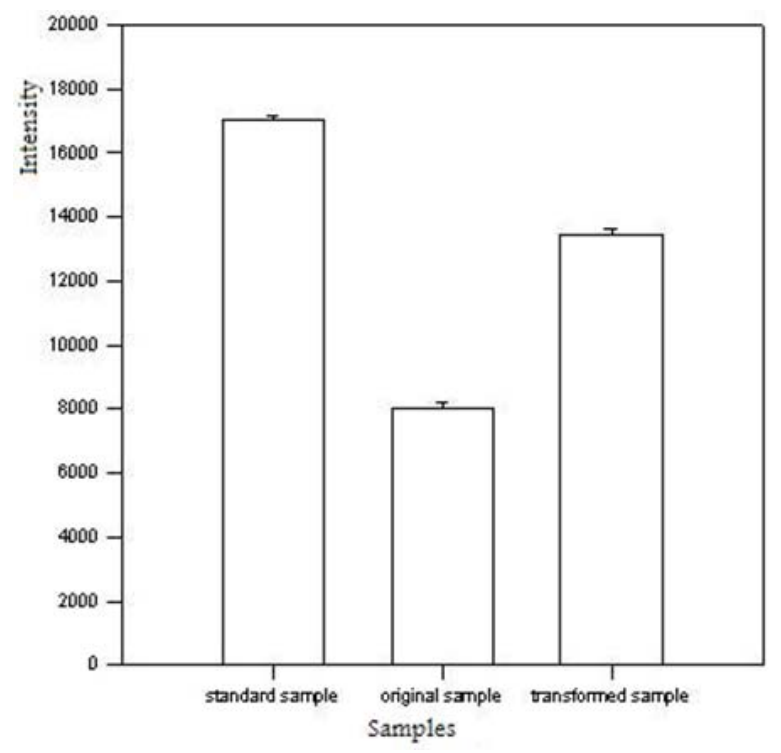

Figure 5. Shows the intensity of the methomyl in studied samples.

MS).The methomyl in the water samples was isolated by solid-phase extraction (SPE) and the recovery rate was 98.9\% (Farré et al. 2002).

In the positive mode of the LC-ESI-MS analysis, carbamate pesticides can be qualitatively and quantitatively analyzed at the level of $0.02 \mu \mathrm{g} / \mathrm{L}$. In addition to protonated ions (M $+\mathrm{H})^{+}$, various molecular adduct ions were observed (Fernández et al. 2000). The spectrum pattern of the extracted methomyl shows molecular ion peaks at $\mathrm{m} / \mathrm{z}[\mathrm{M}$ $+\mathrm{H}]^{+} 163$ which is consistent with methomyl molecular formula $\mathrm{C}_{5} \mathrm{H}_{10} \mathrm{~N}_{2} \mathrm{O}_{2} \mathrm{~S}$ (Figure 2, Figure 3 and Figure 4).

In the original sample (M1-inoculated sample), the intensity of methomyl was significantly reduced (8000 \pm 200 , p < 0.001) when compared with the intensity of standard sample (17033 \pm 152$)$. This confirmed the capability of strain M1 to degrade the methomyl. In the case of the transformed sample (M2-inoculated sample), the intensity of methomyl was significantly reduced (13466 \pm 152 , p < 0.001) compared with the standard sample but was still higher than the sample of the original bacteria as shown in the Figure 5. This may be attributed to the fact that the host strain M2 acquired the ability for methomyl degradation after transformation with PMb plasmid, which encodes the degradative gene (s) from M1 strain. The rate of degradation was slower than M1, which may be due to the slower rate of replication of the transferring plasmid to the host DH5 $\alpha$ strain than the original host. Positive-ion spectra of low molecular weight compounds often comprise simple adduct ions with one or more cations (e.g. $[\mathrm{M}+\mathrm{H}]^{+},[\mathrm{M}+$ $\mathrm{H}+\mathrm{Na}]^{2+}$ ) and cluster ion (e.g. $\left.[2 \mathrm{M}+\mathrm{H}]^{+}\right)$. Therefore the peak lists of LC-ESI-MS measurements can contain hundreds of peaks, and manual inspection of all of them is simply impossible. Therefore, the possibility for the prediction of the degradation pathway of pesticide by this tool is inconvenient.

\section{CONCLUDING REMARKS}

This study demonstrated that the isolated Stenotrophomonas maltophilia M1 strain possesses a strong ability for methomyl degradation. This strain contains two plasmids; one of them (PMb) was believed to be responsible for the degradation of methomyl carrying the degrading gene. This plasmid could be transferred to another bacterial strain in the environment and provide it with methomyl pesticide degradative ability and potentially a selective advantage under a given environmental state.

\section{ACKNOWLEDGEMENTS}

The author is thankful to the staff members in the chemistry department, biochemistry unit, Cairo University for their valuable help.

\section{REFERENCES}

ALEXANDER, Martin. Biodegradation and bioremediation. San Diego, USA; Academic Press, 1999. 453 p. ISBN 978-0-12-049861-1.

CHUNG, Ming Jae and KA, Jong Ok. Isolation and characterization of 2,4-dichlorophenoxyacetic aciddegrading bacteria from paddy soils. The Journal of Microbiology, 1998, vol. 36, no. 4, p. 256-261.

DESAINT, Stéphane; HARTMANN, Alain; PAREKH, Nisha R. and FOURNIER, Jean-Claude. Genetic diversity of carbofuran-degrading soil bacteria. FEMS Microbiology Ecology, December 2000, vol. 34, no. 2, p. 173-180.

DUA, M.; SINGH, A.; SETHUNATHAN, N. and JOHRI, A.K. Biotechnology and bioremediation: successes and limitations, Applied Microbiology and Biotechnology, July 2002, vol. 59, no. 2-3, p.143-152.

DUGUID, J.P. Bacillus. In: COLLEGE, J.G; FRASER, A.G.; MARMION, B.P. and SIMMONS, A. eds. Mackie and McCartney practical medical microbiology. New York, NY; Churchill Livingstone, 1996, $14^{\text {th }}$ Ed. p. 317-327. ISBN 9788131203934.

FARRÉ, M.; FERNÁNDEZ, J.; PAEZ, M.; GRANADA, L.; BARBA, L.; GUTIÉRREZ, H.M.; PULGARÍN, C. and BARCELÓ, D, Analysis and toxicity of methomyl and ametryn after biodegradation. Analytical and Bioanalytical Chemistry, August 2002, vol. 373, no. 8, p. 704-709.

FERNÁNDEZ, M.; PICÓ, Y. and MAÑES, J. Determination of carbamate residues in fruits and vegetables by matrix solid-phase dispersion and liquid chromatography-mass spectrometry. Journal of Chromatography A, February 2000, vol. 871, no. 1-2, p. 4356. 
FURUKAWA, Kensuke. 'Super bugs' for Bioremediation. Trends in Biotechnology, May 2003, vol. 21, no. 5, p. 187190.

HASHIMOTO, Masayuki; FUKUI, Mitsuru; HAYANO, Kouichi and HAYATSU, Masahito. Nucleotide sequence and genetic structure of a novel carbaryl hydrolase gene (cehA) from Rhizobium sp. strain AC100. Applied and Environmental Microbiology, March 2002, vol. 68, no 3, p. 1220-1227.

JUHASZ, A.L.; STANLEY, G.A. and BRITZ, M.L. Microbial degradation and detoxification of high molecular weight polycyclic aromatic hydrocarbons by Stenotrophomonas maltophilia strain VUN 10,003. Letters in Applied Microbiology, May 2000, vol. 30, no. 5, p. 396401.

KARNS, J.S. Molecular genetics of pesticide degradation by soil bacteria. ACS Symposium Series, 1990, vol. 426, p.141-152.

LAEMMLI, Caroline M.; LEVEAU, Johan H.J.; ZEHNDER, Alexander J.B. and VAN DER MEER, Jan Roelof. Characterization of a second $t f d$ gene cluster for chlorophenol and chlorocatechol metabolism on plasmid pJP4 in Ralstonia eutropha JMP134 (pJP4). Journal of Bacteriology, August 2000, vol. 182, no 15, p. 4165-4172.

LEE, E.Y.; JUN, Y.S.; CHO, K.S. and RYU, H.W. Degradation characteristics of toluene, benzene, ethylbenzene, and xylene by Stenotrophomonas maltophilia T3-c. Journal of the Air and Waste Management Association, April 2002, vol. 52, no 4, p. 400-406.

MARECIK, Roman; KRÓLICZAK, Paweł; CZACZYK, Katarzyna; BIAŁAS, Wojciech; OLEJNIK, Anna and CYPLIK, Paweł. Atrazine degradation by aerobic microorganisms isolated from the rhizosphere of sweet flag (Acorus calamus L.). Biodegradation, April 2008, vol. 19, no. 2, p. 293-301.

PIEPER, Dietmar H. and REINEKE, Walter. Engineering bacteria for bioremediation. Current Opinion in Biotechnology, June 2000, vol. 11, no. 3, p. 262-270.

SAYLER, Gary S.; HOOPER, Scott W.; LAYTON, Alice C. and KING, J.M. Henry. Catabolic plasmids of environmental and ecological significance. Microbial Ecology, January 1990, vol. 19, no. 1, p. 1-20.

STRATHMANN, Timothy J. and STONE, Alan T. Reduction of the carbamate pesticides oxamyl and methomyl by dissolved $\mathrm{Fe}^{\mathrm{II}}$ and $\mathrm{Cu}^{\mathrm{I}}$. Environmental Science and Technology, May 2001, vol. 35, no. 12, p. 2461-2469.

TOMLIN, Clive D.S. The Pesticide Manual. BCPC Publications.13 ${ }^{\text {th }}$ Ed. 2003. 1344 p. ISBN 978-1-901396133.
WEISBURG, William G.; BARNS, Susan M.; PELLETIER, Dale M. and LANE, David J. 16S ribosomal DNA amplification for phylogenetic study. Journal of Bacteriology, January 1991, vol. 173, no. 2, p. 697-703. 